\title{
Fibroblast Growth Factor Receptor Family Isoform IIIb
}

National Cancer Institute

\section{Source}

National Cancer Institute. Fibroblast Growth Factor Receptor Family Isoform IIIb. NCI

Thesaurus. Code C121505.

An is oform of fibroblast growth factor receptor-1, -2 , or -3 , where alternative splicing leads to the expression of the IIIb exon encoding the second half of the third immunog lobulin-like domain, which is located in the extracellular domain of these receptors. This variant is expressed in epithelial lineage cells and has differential lig and binding activity when compared to the IIIa and IIIC forms. 